\title{
Enzymes and Cancer
}

\section{PREPARATION AND SOME PROPERTIES OF GUANASE FROM RABBIT LIVER}

\author{
BY R. CURRIE,* F. BERGEL AND R. C. BRAY \\ Chester Beatty Research Institute, Institute of Cancer Research: Royal Cancer Hospital, \\ London, S.W. 3
}

(Received 6 January 1967)

\begin{abstract}
1. Guanase has been purified 200 -fold in $20 \%$ yield from the supernatant fraction of rabbit-liver homogenates, by using ammonium sulphate fractionation, calcium phosphate-gel adsorption and chromatography on DEAE-cellulose and Sephadex G-200. 2. $K_{m}$ with guanine as substrate at the optimum $\mathrm{pH}$ of $7 \cdot 7$ was found to be $1.05 \times 10^{-5} \mathrm{M}$. $Q_{10}$ was 1.4 between $23^{\circ}$ and $48^{\circ}$. 3. Substrate activity and $\mathrm{pH}$ optima of compounds related to guanine have been studied. 8-Azaguanine, 1 methylguanine, thioguanine and 1-methylthioguanine are all substrates.
\end{abstract}

During our investigations of enzymes that might control metabolic events, particularly in neoplastic tissues, we carried out an extensive study of xanthine oxidase (see Bray, 1963). It appeared logical to extend such investigations to include other enzymes of purine metabolism. Of these, guanase (guanine aminohydrolase, EC 3.5.4.3) was of special interest as guanine is metabolically a precursor of xanthine and is thus indirectly a source of uric acid.

Guanase was discovered by Schmidt (Schmidt, 1932 ; Schmidt \& Engel, 1932) in rabbit liver and is present in tissues of other animals (Greenstein, Carter, Chalkley \& Leuthardt, 1946; Block \& Johnson, 1955; Hall, Levine \& Harris, 1961; Roy, 1966), in certain bacteria (Rakosky \& Beck, 1955; Rashba \& Tsinskalovska, 1956) and in the adapted yeast Torula utilis (Roush, 1954). Partial purification of the enzyme has been reported from rabbit liver (Hitchings, \& Falco, 1944), rat liver (Kalckar, 1947) and Clostridium acidiurici (Rakosky, Zimmerman \& Beck, 1955), with few indications of the degree of purification and yield. Mansoor, Kalyankar \& Talwar (1963) have published a procedure for purification of the enzyme from rat brain and, since this work (Currie, 1965) was completed, Roy (1966) has purified the enzyme from ling-cod muscle. Both of these more recent preparations appear to differ in some kinetic properties from those of liver extracts.

A comparison (R. Yasin, unpublished work) of the activities of liver extracts from mouse, rat, calf, pig, ox, chicken, sheep, horse, dog, rabbit and man indicated that rabbit liver was the best available

\footnotetext{
* Present address: Laboratorius voor Biochemie, Plantage Muidergracht 12, Amsterdam, The Netherlands.
}

source. The present paper describes a convenient partial purification of the enzyme from this source and some of its properties.

\section{MATERIALS AND METHODS}

Materials. Analytical-reagent grades were generally employed where these were available. Special materials were obtained from the following sources: ribonuclease (bovine, crystalline, was from Armour Pharmaceutical Co. Ltd. (Eastbourne, Sussex); deoxyribonuclease (crystalline) was from L. Jight and Co. Ltd. (Colnbrook, Bucks); lactate dehydrogenase $\left[\left(\mathrm{NH}_{4}\right)_{2} \mathrm{SO}_{4}\right.$ suspension] was from British Drug Houses Ltd. (Poole, Dorset); xanthine oxidase was obtained from cow's milk by the method of Palmer, Bray \& Beinert (1964); Amido Black (Naphthalene Black 10B) and nitro-blue tetrazolium were from $\mathbf{E}$. Gurr Ltd. (London, S.W. 14); starch for electrophoresis was from Connaught Medical Laboratories (Toronto, Canada); guanine was from C. F. Boehringer und Soehne G.m.b.H. (Mannheim, Germany); 8-azaguanine was from Sigma Chemical Co. (St Louis, Mo., U.S.A.); 1-methylguanine was from Dr C. Reese (University of Cambridge); 8-bromoguanine (C grade) was from Calbiochem (Los Angeles, Calif., U.S.A.); 2,6diaminopurine, thioguanine, thioazaguanine disulphide and 4-hydroxy-6-aminopyrazolo-(3,4d)-pyrimidine were kindly supplied by Dr G. Hitchings (Wellcome Research Laboratories, Tuckahoe, N.Y., U.S.A.); DEAE-cellulose was from Calbiochem; calcium phosphate gel was prepared by the method of Tiselius, Hjerten \& Levin (1956); Sephadex G-200 was from Pharmacia (Uppsala, Sweden). Saturated $\left(\mathrm{NH}_{4}\right)_{2} \mathrm{SO}_{4}$ solutions were prepared as follows. Glass-distilled water was saturated with $\left(\mathrm{NH}_{4}\right)_{2} \mathrm{SO}_{4}$ at room temperature and the $\mathrm{pH}$ was adjusted to 9.0 with aq. $\mathrm{NH}_{3}$. The solution was kept overnight to allow for precipitation of any $\mathrm{Fe}(\mathrm{OH})_{3}$. The solution was filtered and then adjusted to the required $\mathrm{pH}$ with $\mathrm{H}_{2} \mathrm{SO}_{4}$. The $\left(\mathrm{NH}_{4}\right)_{2} \mathrm{SO}_{4}$ solution was placed at $3^{\circ}$ for at least $24 \mathrm{hr}$. before use.

Spectrophotometric and ammonia production assay of guanase activity. Measurements were carried out with a 
Unicam SP. 500 spectrophotometer with a Gilford recording attachment at $37^{\circ}$ and with a mixture containing sodium pyrophosphate buffer, pH8.2 (50 mM), guanine $(67 \mu \mathrm{M})$ and enzyme in a final volume of $3.0 \mathrm{ml}$. The reaction was started by adding the enzyme at a suitable dilution and continuous recording of the rate of $E_{250}$ decrease was used to obtain the initial rate. The 'unit' of enzyme activity as mentioned in this paper is defined as that amount of enzyme which is required to produce an $E_{250}$ change of 0.01 unit/min. under the conditions of assay; the specific activities of the enzyme samples were expressed as units/mg. of protein.

When guanase activity was measured by $\mathrm{NH}_{3}$ production the assay mixture consisted of: $0.1 \mathrm{M}$-sodium pyrophosphate $(2.8 \mathrm{ml}$.) adjusted to the $\mathrm{pH}$ being used, 1 mm-guanine $(0.2 \mathrm{ml}$.) and enzyme solution of a suitable dilution $(0.1 \mathrm{ml}$.). A blank solution without enzyme was also set up. The mixtures were incubated at $37^{\circ}$ for suitable time-intervals, then the reaction was stopped by the addition of $20 \%(w / v)$ trichloroacetic acid (1.0 ml.). The $\mathrm{NH}_{3}$ produced in $0.1 \mathrm{ml}$. of each of the samples was assayed by the method of Konitzer \& Voigt (1963). The quantities of $\mathrm{NH}_{3}$ were plotted against the time of incubation and the initial rate obtained was used as a measure of enzyme activity.

Assay of lactate-dehydrogenase activity. Lactate-dehydrogenase activity was assayed spectrophotometrically at $340 \mathrm{~m} \mu$ by the method of Wu \& Racker (1959).

Preparation of columns. DEAE-cellulose was treated with approx. $\mathrm{N}-\mathrm{NaOH}$ for at least $30 \mathrm{~min}$. and then washed free of most of the alkali and poured into columns as a slightly alkaline suspension. When the DEAE-cellulose was packed to the desired height it was washed with distilled water until the effluent was neutral. Equilibrating buffer was allowed to flow slowly through the column at about $3^{\circ}$. When the effluent attained the same $\mathrm{pH}$ as that of the ingoing buffer the column was ready for the protein solution to be applied. Exponential gradients were set up according to the method of Bock \& Ling (1954).

Dry Sephadex G-200 was stirred into ammonium phosphate buffer, pH 7.3 and $I 0 \cdot 05$, and kept at room temperature for 5-6 days. Buffer and suspension were deaerated by evacuation. The column, with an extension tube of at least equal length, filled with buffer at room temperature and the gel suspension was then run into the top of the column at the same rate as buffer was run out. The buffer in the top of the column was slowly stirred (Andrews, 1964). When the gel grains had settled to the required height, the extension tube was removed and the column was washed in the cold with buffer.

Starch-gel electrophoresis. Special starch (12.2g./100ml.) was suspended in $8.6 \mathrm{~mm}-\mathrm{Na}_{2} \mathrm{HPO}_{4}-0.14 \mathrm{~mm}$-citric acid buffer, pH 7.0, and heated with continuous swirling in a Buchner flask over a naked flame, until the starch solution was just boiling. The stoppered flask was then attached to a pump to reduce the air pressure and the solution was swirled until boiling ceased. The hot liquid starch solution was quickly poured into a Perspex container $(18 \mathrm{~cm} . \times 9 \mathrm{~cm} . \times 2 \mathrm{~cm}$.). The top of the starch gel was flattened with a Perspex sheet and then left at $3^{\circ}$ for at least $1 \mathrm{hr}$. to set.

The enzyme solution ( $50 \mu \mathrm{l}$. containing 3-4mg.) on Whatman no. 42 filter paper was placed in a cut in the gel. A potential of $6 \mathrm{v} / \mathrm{cm}$. was applied to the gel at $3^{\circ}$ for $4 \mathrm{hr}$. The electrode buffer used was $89 \mathrm{~mm}-\mathrm{Na}_{2} \mathrm{HPO}_{4}-11$ mM-citric acid buffer, $\mathrm{pH} 7 \cdot 0$.

Transverse sections of the gel were cut and the protein in one section was stained with saturated Amido Black in methanol-water-acetic acid (5:5:1, by vol.) for $1 \mathrm{~min}$. The free Amido Black was then washed away with methanolacetic acid-water (5:5:1, by vol.) until the background gel was colourless. The other transverse sections were stained for guanase activity as follows: nitro-blue tetrazolium (10 mg.) was dissolved in 0.1 M-tris buffer, pH8.0 (52 ml.), and added to $1 \mathrm{~mm}$-guanine $(8.0 \mathrm{ml}$.). Xanthine oxidase (2ml., $0.5 \%$ solution) was added and a slice of the starch gel incubated in this solution at $37^{\circ}$ for $30-60 \mathrm{~min}$. The position of the guanase activity, via the reduction of the tetrazolium reagent by xanthine oxidase, could be located by the appearance of a mauve-blue area.

Purification. R. Yasin (unpublished work) carried out a survey of guanase concentration in livers of a number of animals. From this it was concluded that the enzyme activity in the livers of dog, mouse, rat, man and rabbit was distinctly higher than that in the livers of calf, pig, ox, chicken, sheep and horse. The highest activity was found in rabbit liver. This was therefore selected as starting material. The final purification procedure is summarized below and in Table 1: all operations were carried out at $0-5^{\circ}$.

Stage 1. Fresh rabbit liver from a commercial slaughter. house was cut into dices and then homogenized in a Waring Blendor in 2vol. of $49 \mathrm{~mm}$-ammonium phosphate buffer, pH5.0 and 10.05 . The pH of the homogenate was carefully adjusted to $5 \cdot 0$ with approx. $\mathrm{N}$-acetic acid. The homogenate was then left for $2-4 \mathrm{hr}$. before centrifugation at $41000 \mathrm{~g}$ for $20 \mathrm{~min}$. The red-brown supernatant was decanted and filtered through muslin to remove any floating lipid or protein.

Stage 2. The supernatant was brought to $40 \%$ saturation by dropwise addition of saturated $\left(\mathrm{NH}_{4}\right)_{2} \mathrm{SO}_{4}$ solution, $\mathrm{pH} 6 \cdot 6$, and left for at least $1 \mathrm{hr}$. before centrifugation at $1000 \mathrm{~g}$ for $30 \mathrm{~min}$. The supernatant obtained was then brought to $75 \%$ saturation with respect to $\left(\mathrm{NH}_{4}\right)_{2} \mathrm{SO}_{4}$ and left for $2-3 \mathrm{hr}$. before centrifugation at $1000 \mathrm{~g}$ for $30 \mathrm{~min}$. The 40-75\%-saturated $\left(\mathrm{NH}_{4}\right)_{2} \mathrm{SO}_{4}$ precipitate was dissolved in a minimum volume of $50 \mathrm{~mm}$-ammonium acetate buffer, pH5.8 and I0.05.

\section{Table 1. Preparation of guanase from rabbit liver}

\section{Fraction}

pH5.0 tissue extract $40-75 \%$-satd. $\left(\mathrm{NH}_{4}\right)_{2} \mathrm{SO}_{4}$ fraction Calcium phosphate fraction DEAE-cellulose chromatography Sephadex-G-200-gel filtration

$\begin{array}{cc}\text { Stage } & \begin{array}{c}\text { Total enzyme } \\ \text { (units/kg. of liver }\end{array} \\ 1 & 52000 \\ 2 & 52000 \\ 3 & 28600 \\ 4 & 13500 \\ 5 & 11400\end{array}$

Specific
activity
$\mathbf{0 \cdot 2 5}$
$\mathbf{1 \cdot 8}$
$\mathbf{7 \cdot 4}$
$\mathbf{3 1}$
$\mathbf{5 1}$

$\begin{array}{cc}\text { Purification } & \text { Yield (\%) } \\ - & 100 \\ 7 \cdot 2 \times & 100 \\ 32 \times & 55 \\ 124 \times & 26 \\ 202 \times & 20\end{array}$


Stage 3. The solution was dialysed against $50 \mathrm{~mm}-$ ammonium acetate buffer, $\mathrm{pH} 5.8$ and $I 0.05$ (two changes each of 20-30 vol.), and then mixed with calcium phosphate gel equilibrated with the same acetate buffer: $20 \mathrm{~g}$. of calcium phosphate gel was used for the extract from $200 \mathrm{~g}$. of liver. The $\mathrm{pH}$ of the suspension was adjusted to 5.0 with N-acetic acid. The suspension was stirred slowly for $2 \mathrm{hr}$. and then centrifuged at $1000 \mathrm{~g}$ for $10 \mathrm{~min}$. The supernatant, which still contained a small percentage of the enzyme activity, was discarded and the gel was washed with a small amount of $80 \mathrm{~mm}$-ammonium phosphate buffer, pH7.5 and $10.2(30 \mathrm{ml}$. of buffer $/ 20 \mathrm{~g}$. of gel), and this washing discarded. The gel was then eluted five times with 80mM-ammonium phosphate buffer, $\mathrm{pH} 7.5$ and $I 0.2$ $(50 \mathrm{ml}$. of buffer $/ 20 \mathrm{~g}$. of gel), and the eluate retained.

Stage 4. Saturated $\left(\mathrm{NH}_{4}\right)_{2} \mathrm{SO}_{4}$ solution, $\mathrm{pH} 6 \cdot 6$ (3 vol.), was added to bring the eluate to $75 \%$ saturation. The mixture was left for $2 \mathrm{hr}$. before centrifugation at $1000 \mathrm{~g}$ for $45 \mathrm{~min}$. The precipitate was dissolved in the minimum volume of $19 \mathrm{~mm}$-ammonium phosphate buffer, $\mathrm{pH} 7 \cdot 3$ and $I 0.04$, to which had been added $1 \mathrm{mg}$. each of ribonuclease and deoxyribonuclease. The solution was then dialysed overnight (against $19 \mathrm{~mm}$-ammonium phosphate buffer, pH 7.3) to allow the enzymes time to hydrolyse any nucleic acids present, with two changes, each of $20 \mathrm{vol}$. (If the enzymic treatment was omitted, the purification achieved in the subsequent chromatography was less complete.) The protein solution was run on to a DEAE-cellulose column (770 ml. packed volume for $1 \mathrm{~g}$. of protein) that had previously been equilibrated with $19 \mathrm{~mm}$-ammonium phosphate buffer, $\mathrm{pH} 7 \cdot 3$. The column was then washed with $19 \mathrm{~mm}$ ammonium phosphate buffer, $\mathrm{pH} \mathbf{7 \cdot 3}$, until enzyme activity was just beginning to be eluted ( 0.5 column vol. of buffer). The eluting buffer was changed to $120 \mathrm{~mm}$-ammonium phosphate buffer, $\mathrm{pH} 7 \cdot 3$ and $I 0 \cdot 25$, and $3 \mathrm{ml}$. fractions were collected until no further protein was eluted from the column. The fractions were assayed for both protein concentration and enzyme activity and those fractions of specific activity greater than 25 were pooled.

Stage 5. The pooled fractions were concentrated to approx. $50 \mathrm{mg} . / \mathrm{ml}$. on a vacuum dialyser (Membranfiltergesellschaft, Göttingen, Germany) and run through a column of Sephadex G-200 previously equilibrated with 19M-ammonium phosphate buffer, $\mathrm{pH} 7 \cdot 3$ and $I 0.04$ $(2.5 \mathrm{~cm} . \times 45 \mathrm{~cm}$. column for up to $50 \mathrm{mg}$. of protein $)$. The protein was washed through the column with $19 \mathrm{~mm}$ -

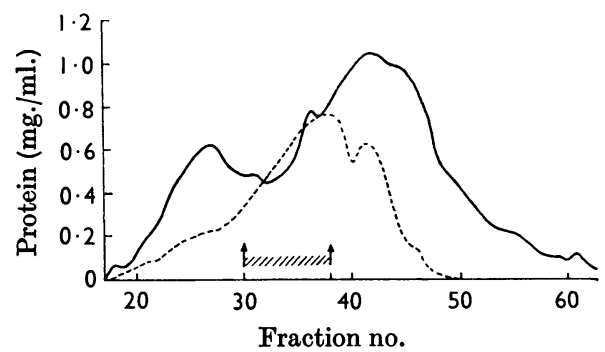

Fig. 1. Gel filtration of guanase (stage 4) on Sephadex G-200 at $\mathrm{pH} 7 \cdot 3$. - Protein concentration; ...., guanase activity. The shaded section indicates the range of fractions pooled. ammonium phosphate buffer, $\mathrm{pH} 7 \cdot 3$ and $I 0 \cdot 04$. Fractions $(2 \mathrm{ml}$.) were collected and assayed for enzyme activity and protein concentration (Fig. 1). Fractions of specific activity greater than 40 were retained and pooled. The width and asymmetry of the activity band suggested that aggregation of the enzyme may have occurred. (If the gel filtration was carried out at $\mathrm{pH5 \cdot 7}$ this aggregation was much more marked.)

At this stage the specific activity was approx. 50, corresponding to a 200-fold purification of the initial tissue extract, and the yield was $20 \%$. However, the enzyme was not completely pure, since it showed guanosine-phosphorylase activity and since, after starch-gel electrophoresis, staining indicated that protein and activity were not fully coincident.

\section{RESULTS}

The enzyme purified by the procedure described above had the following properties.

Storage. Enzyme solution could be stored for long periods (tested up to 6 months) in $40 \%$-saturated ammonium sulphate at $\mathrm{pH} 6.6$ and $-13^{\circ}$. If the solutions were cooled down to $-35^{\circ}$ then a large proportion of the activity was lost; the same loss occurred after repeated freezing and thawing. The enzyme solutions are also much more stable to dialysis in ammonium than in sodium or potassium phosphate buffers.

Molecular weight. Gel-filtration behaviour has been used to determine molecular weights of proteins (see Andrews, 1964) in that $\log$ (molecular weight) was shown to be directly proportional to the volume of solution necessary to elute the compound from a standardized column.

A mixture of the proteins xanthine oxidase, lactate dehydrogenase and cytochrome $c$ was placed on to a column of Sephadex G-200 (see the Materials and Methods section), washed through with phosphate buffer, $\mathrm{pH} 7 \cdot 3$, and the fractions were assayed for enzyme activity and protein concentration. Purified guanase (stage 5) gave a skewed peak of enzyme activity, suggesting multimolecular forms of the enzyme. The main peak indicated a molecular weight of 170000 , and a shoulder corresponded to a molecular weight of about 525000 .

Effect of $\mathrm{pH}$ on enzyme activity. Liver guanase has been reported to have a broad $\mathrm{pH}$ optimum with a maximum at about $\mathrm{pH} 9.0$ with guanine as substrate (Schmidt, 1932; Roush \& Norris, 1950; Takahashi, 1954), but a sharp pH-activity curve reaching its peak at $\mathrm{pH} 6.3$ when 8-azaguanine was used as substrate (Roush \& Norris, 1950). The purified guanase described in this paper was tested with three substrates: guanine, 8-azaguanine and 1methylguanine in the range $\mathrm{pH} 4.5-11.5$ at $37^{\circ}$. The pH-activity curves showed a relatively sharp maximum at $\mathrm{pH} 5.9$ for 8-azaguanine, and slightly broader maxima at $\mathrm{pH} 7 \cdot 1$ for 1-methylguanine and at $\mathrm{pH} \mathrm{7.7}$ for guanine (Fig. 2). 


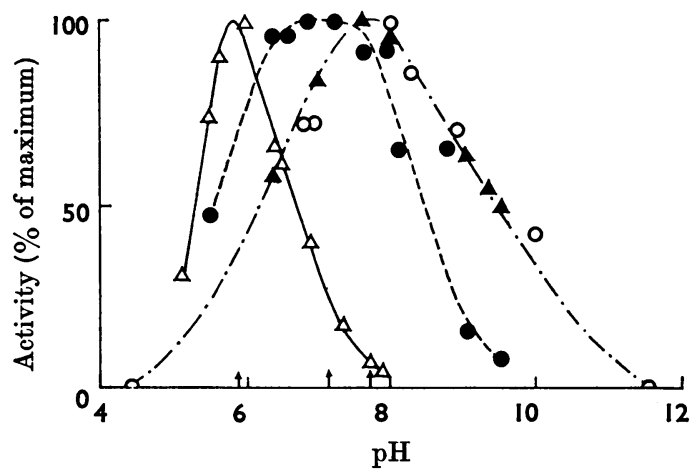

Fig. 2. pH-activity curves for purified guanase with the following substrates: guanine (-.-.); 1-methylguanine (---); 8-azaguanine (-). $\triangle, O$ and $\bullet$, Ammonia determination method; $\boldsymbol{\Delta}$, spectrophotometric method.

Table 2. $K_{m}$ values of rabbit-liver guanase at the optimum $\mathrm{pH}$ values for each of the three substrates

Incubations were at $37^{\circ}$ in $0 \cdot 1$ M-sodium pyrophosphatecitrate buffer.

\begin{tabular}{lcc}
\multicolumn{1}{c}{ Substrate } & Optimum $\mathrm{pH}$ & $10^{5} \mathrm{~K}_{m}(\mathrm{M})$ \\
Guanine & $7 \cdot 7$ & $1 \cdot 05$ \\
8-Azaguanine & $5 \cdot 9$ & $10 \cdot 2$ \\
l-Methylguanine & $7 \cdot 1$ & 270
\end{tabular}

Substrate concentration. Values for $K_{m}$ were obtained for each substrate at its $\mathrm{pH}$ optimum in 0.1 M-pyrophosphate-citrate buffer by drawing the usual Lineweaver-Burk graphs. Results are given in Table 2.

Temperature effect. Guanase activity in $0.1 \mathrm{~m}$ sodium pyrophosphate buffer, $\mathrm{pH} 7 \cdot 7$, with $67 \mu \mathrm{M}$ guanine was measured between $23^{\circ}$ and $48^{\circ}$. A linear plot was obtained and $Q_{10}$ was calculated to be $1 \cdot 4$.

Deamination of guanine analogues. Solutions ( $10 \mathrm{~mm}$ ) of 2,6-diaminopurine, 1-methylthioguanine, thioguanine, thioazaguanine disulphide and 4hydroxy-6-aminopyrazolo-(3,4d)-pyrimidine were prepared and mixed with the enzyme in $0.1 \mathrm{M}$ sodium pyrophosphate buffer, $\mathrm{pH} 6 \cdot 5$. After incubation at $37^{\circ}$ for $3 \mathrm{hr}$. the reaction was stopped by the addition of perchloric acid. The only substrates that showed any measurable ammonia liberation were thioguanine and 1-methylguanine with respectively $0.75 \%$ and $0.36 \%$ compared with the guanine $100 \%$ degradation.

\section{DISCUSSION}

There is no doubt that the present preparation of guanase could be further improved. However, the purity and yield compare with the preparation by Mansoor et al. (1963) from rat brain and with that of Roy (1966) from ling-cod muscle. In the present case and also in that of Mansoor et al. (1963) five major steps are required to produce an enzyme concentrate of about the same specific activity. The method of Roy (1966) has three major steps. The overall yield obtained in the present method was $20 \%$, whereas that of other investigators was about $5 \%$.

Guanases from different sources do not appear to be identical. The enzymes from both rat and sheep brain exhibit a double peak of optimum activity at pH 6.5 and pH 8.5-9.0 in tris-acetate buffers with guanine as substrate (Mansoor et al. 1963), whereas the crude extract of ling-cod muscle has double peaks of activity at $\mathrm{pH} 5 \cdot 6$ and $\mathrm{pH} 8.5$ (Roy, 1966). On heat treatment, however, this enzyme only exhibits a single optimum at pH 6.0. The optimum activity of the enzyme from rabbit liver with guanine as substrate was found to be at $\mathrm{pH} 7.7$ in pyrophosphate-citrate buffers. As stated above, previous workers have reported a broad $\mathrm{pH}$ optimum for the crude rabbit-liver enzyme at approx. $\mathrm{pH} 9 \cdot 0$. The purified rabbit-liver enzyme appears to manifest a much sharper $\mathrm{pH}$-activity curve than that exhibited by the crude enzyme. Optimum activity with 8-azaguanine as substrate is at pH5.9 in pyrophosphate-citrate buffers. This value is again somewhat lower than that obtained by other workers with a crude enzyme preparation, i.e. pH 6.5 (Roush \& Norris, 1950).

The present $K_{m}$ value with guanine as substrate also differs from that reported for the rat-brain enzyme, but, since measurements were carried out at different $\mathrm{pH}$ values, no definite comparison can be made.

Roy (1966) could only demonstrate the deamination by the fish guanase of guanine and 8-azaguanine, whereas Mansoor et al. (1963) found that guanase from rat brain would deaminate thioguanine as well. Purified rabbit-liver guanase will deaminate guanine, 8-azaguanine, 1-methylguanine, thioguanine and 1-methylthioguanine. Hitchings \& Falco (1944) demonstrated that the enzyme from rabbit liver did not deaminate adenine, 7-methyl. guanine or 1,7-dimethylguanine. Thus the nature of the group at position 6 of the purine ring is very important in relation to enzyme activity. Deamination of the 2-amino group occurs with a hydroxyl or thiol group in position 6 (though in the latter case the substrate affinity is lowered), but not with an amino group, i.e. 2,6-diaminopurine is not deaminated. Methylation at position 1 of the ring allows a much diminished rate of deamination to occur, and on methylation at position 7 no deamination occurs at all. The replacement of the $-\mathrm{CH}=$ group at position 8 of the ring by an $-\mathrm{N}=$ group 
also lowers this affinity. Thus the groups at positions 2, 6, 7 and 8 are all critical for activity.

We thank Dr C. Reese and Dr G. Hitchings for gifts of materials. This investigation has been supported by grants to the Chester Beatty Research Institute (Institute of Cancer Research: Royal Cancer Hospital) from the Medical Research Council and the British Empire Cancer Campaign for Research, and by Publio Health Service Research Grant no. CA-03188-10 from the National Cancer Institute, U.S. Public Health Service. The work was carried out during the tenure of a Royal Marsden Hospital Fellowship by R.C.

\section{REFERENCES}

Andrews, P. (1964). Biochem. J. 91, 222.

Block, W. D. \& Johnson, D. V. (1955). J. biol. Chem. $217,43$. Bock, R. M. \& Ling, N. (1954). Analyt. Chem. 26, 1543.

Bray, R. C. (1963). In The Enzymes, vol. 7, p. 533. Ed. by Boyer, P. D., Lardy, H. \& Myrbäck, K. New York: Academic Press Inc.

Currie, R. (1965). Ph.D. Thesis: University of London.

Greenstein, J. P., Carter, C. E., Chalkley, H. W. \& Leuthardt, F. M. (1946). J. nat. Cancer Inst. 7, 9.
Hall, T. G., Levine, R. \& Harris, C. A. (1961). Biochem. Pharmacol. 8, 71.

Hitchings, G. H. \& Falco, E. A. (1944). Proc. nat. Acad. Sci., Wash., 30, 294.

Kalckar, H. M. (1947). J. biol. Chem. 167, 461.

Konitzer, K. \& Voigt, S. (1963). Clin. chim. Acta, 8, 5.

Mansoor, M., Kalyankar, G. D. \& Talwar, G. P. (1963). Biochim. biophys. Acta, 77, 307.

Palmer, G., Bray, R. C. \& Beinert, H. (1964). J. biol. Chem. 239, 2657.

Rakosky, J. \& Beck, J. V. (1955). J. Bact. 69, 563.

Rakosky, J., Zimmerman, L. N. \& Beck, J. V. (1955). J. Bact. 69, 566.

Rashba, O. Y.\& Tsinskalovska, S. M. (1956). Mikrobiol. Zh., Kiev., 18, 30.

Roush, A. H. (1954). Arch. Biochem. Biophys. 50, 510.

Roush, A. \& Norris, E. R. (1950). Arch. Biochem. Biophys. 29, 124.

Roy, J. E. (1966). Canad. J. Biochem. 44, 1093.

Schmidt, G. (1932). Hoppe-Seyl. Z. 208, 185.

Schmidt, G. \& Engel, E. (1932). Hoppe-Seyl. Z. 208, 225. Takahashi, T. (1954). Gann, 45, 631.

Tiselius, A., Hjerten, S. \& Levin, D. (1956). Arch. Biochem. Biophys. 65, 132.

Wu, R. \& Racker, E. (1959). J. biol. Chem. 234, 1029. 